\title{
16. INTERSTITIAL WATER CHEMISTRY: DEEP SEA DRILLING PROJECT, LEG 9
}

\author{
B. J. Presley ${ }^{1}$ and I. R. Kaplan, \\ Department of Geology and Institute of Geophysics and Planetary Physics, \\ University of California, Los Angeles, California
}

\section{INTRODUCTION}

The interstitial water received at UCLA from Leg 9 (Tahiti to Panama) consisted of twenty-three samples of approximately 5 milliliters each, four samples of approximately 10 milliliters each, and four samples of approximately 100 milliliters each. These pore waters had been squeezed from sediments consisting primarily of biogenic ooze, and had been collected at five different drilling sites along the route.

All water was filtered through a 0.45 -micron membrane filter on board ship immediately after squeezing. The 5-milliliter samples were then sealed in plastic syringes, and were kept refrigerated except for the time in shipment to UCLA. The 100-milliliter samples were also kept refrigerated, but were stored in plastic bottles. The 10-milliliter samples were frozen in polyethylene bottles on board ship, and were kept frozen until analysis had begun.

Analysis was started as soon as the samples had arrived at UCLA; nevertheless, as much as three months had then elapsed since collection.

\section{EXPERIMENTAL PROCEDURES}

The analytical procedures currently being used in the UCLA interstitial water program are described elsewhere (Presley, 1971; Presley and Claypool, 1971). These procedures have evolved during the course of the Deep Sea Drilling Program, as a result of attempts to obtain more and better data from the small samples available. The analytical precision to be expected in working with samples of this size and composition is also discussed in the references, but slightly larger errors may have been introduced into some Leg 9 samples due to differential evaporation during handling.

The procedures used for the Leg 9 samples are not in all cases exactly the same as those described in the references given above, but most changes are too minor to warrant mention. Slight changes will continue to be made for future samples when it seems that this will result in better precision.

\footnotetext{
${ }^{1}$ Present address: Department of Oceanography, Texas A\&M University, College Station, Texas.
}

\section{RESULTS AND DISCUSSION}

The data obtained from the 5-milliliter samples are presented in Table 1, but major cation concentrations which were determined have been omitted, because these can be found in the report by Manheim et al. (this volume). Data obtained from the 100-milliliter samples and from the frozen samples can be found in Table 2.

The trace metals iron, cobalt, nickel and copper can only be determined on relatively large volume samples by our present techniques, and these are limited to four or fewer in number for each leg by a directive from the DSDP Interstitial Water Panel. The four samples collected on Leg 9 show concentrations similar to those found in the biogenic oozes from Legs 6, 7 and 8 , except for two very high iron values and one high copper value from Leg 8 , and the apparently lower cobalt concentrations here.

The significance of these variations in concentration is difficult to assess when so few samples are available for analysis, and when sampling and shipboard handling could introduce serious contamination. It is interesting to note, however, that previous preliminary hole summaries have specifically mentioned sediment contamination by rust from the drill pipe, yet water squeezed from these sediments has not been enriched in iron or other trace metals. Perhaps, then, contamination during sampling is not actually a serious problem.

The highest dissolved iron concentration in the Leg 9 samples was found at Site 79 , in sediments reported in the preliminary hole summaries to contain "manganese crusts." This sediment was also enriched in dissolved manganese, as was sediment from Site 83 where "manganese laminations" were reported. On the other hand, pore water from sediments containing "Mn-Fe oxides and $\mathrm{FeS}_{2}$ " (Site 82) was much lower in manganese and iron content. Once again, then, the variations in heavy metal concentration, especially that of manganese, seem not to be simply related to sediment type or measured or implied redox conditions.

Boron concentrations in the present samples tend to be somewhat higher than is typical of seawater, but there 
TABLE 1

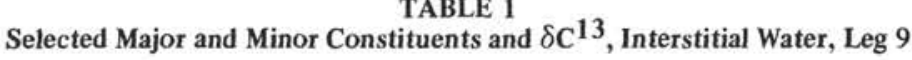

\begin{tabular}{|c|c|c|c|c|c|c|c|c|c|c|c|}
\hline $\begin{array}{c}\text { Sample } \\
\text { Designation }\end{array}$ & $\underset{(\mathrm{m})}{\text { Depth }^{\mathrm{b}}}$ & Age & Description of Sediment & $\underset{(\mathrm{g} / \mathrm{kg})}{\mathrm{a}}$ & $\begin{array}{c}\mathrm{Br} \\
(\mathrm{mg} / \mathrm{kg})\end{array}$ & $\begin{array}{c}\mathrm{B} \\
(\mathrm{mg} / \mathrm{kg})\end{array}$ & $\begin{array}{c}\mathrm{Mn} \\
(\mu \mathrm{g} / \mathrm{kg})\end{array}$ & $\underset{(\mathrm{mM} / \mathrm{kg})}{\Sigma \mathrm{CO}}$ & $\underset{(\mathrm{mM} / \mathrm{kg})}{\Sigma \mathrm{CO}_{2}{ }^{3}}$ & $\begin{array}{l}\delta \mathrm{C}^{13} \\
(\mathrm{PDB})\end{array}$ & $p \mathrm{H}^{\mathrm{c}}$ \\
\hline $77 \mathrm{~B}-1-5$ & 10 & Pleistocene & Interbedded white-yellow-grey $\mathrm{SiO}_{2}-\mathrm{CaCO}_{3}$ ooze & 19.6 & 67 & 5.5 & 3900 & 2.71 & 2.35 & -1.48 & 7.6 \\
\hline $77 \mathrm{~B}-8-4$ & 78 & Pliocene & Interbedded white-blue-purple $\mathrm{SiO}_{2}-\mathrm{CaCO}_{3}$ ooze & 19.6 & 70 & 5.8 & 370 & 3.14 & 2.79 & +0.07 & 7.5 \\
\hline $77 \mathrm{~B}-12-2$ & 110 & Upper Miocene & Interbedded white-green-purple $\mathrm{SiO}_{2}-\mathrm{CaCO}_{3}$ ooze & 20.2 & 74 & - & 340 & 3.74 & 3.21 & -1.50 & 7.6 \\
\hline $77 \mathrm{~B}-16-6$ & 152 & Upper Miocene & Interbedded white-green-purple $\mathrm{SiO}_{2}-\mathrm{CaCO}_{3}$ ooze & 19.5 & 71 & 6.1 & 210 & 3.93 & 3.28 & - & 7.6 \\
\hline 77B-20-4 & 185 & Middle Miocene & Massive white chalk, with radiolarians & 19.9 & 72 & - & $<50$ & 3.85 & 3.42 & +0.71 & 7.5 \\
\hline $77 \mathrm{~B}-24-4$ & 222 & Middle Miocene & Massive white chalk, with radiolarians & 19.3 & 67 & 5.7 & $<50$ & 3.77 & 3.68 & +1.02 & 7.6 \\
\hline 77B-28-4 & 265 & Lower Miocene & Interbedded orange-grey chalk, radiolarians & 19.5 & 68 & 6.0 & $<390$ & 3.52 & - & -4.08 & 7.7 \\
\hline 77B-32-5 & 297 & Lower Miocene & Massive white chalk, trace $\mathrm{SiO}_{2}$ ooze & 19.9 & - & 6.1 & $<50$ & 3.58 & 2.96 & - & 7.6 \\
\hline $77 \mathrm{~B}-40-2$ & 334 & Upper Oligocene & Massive white chalk, $5-10 \% \mathrm{SiO}_{2}$ ooze & 19.4 & 68 & - & $<50$ & 3.52 & 2.81 & -0.97 & 7.6 \\
\hline $77 \mathrm{~B}-45-1$ & 410 & Upper Oligocene & Massive white-orange chalk, $5-10 \% \mathrm{SiO}_{2}$ ooze & 19.9 & - & 6.5 & $<50$ & 2.89 & 2.11 & - & 7.7 \\
\hline $77 \mathrm{~B}-48-5$ & 443 & Lower Oligocene & Bedded chalk- $\mathrm{SiO}_{2}$ ooze chalk & 19.7 & 69 & 5.4 & $<50$ & 2.89 & 2.33 & +0.13 & 7.7 \\
\hline $77-1-5$ & 17 & Middle Miocene & Pale orange $\mathrm{CaCO}_{3}$ ooze, minor clay- $\mathrm{SiO}_{2}$ ooze & 19.8 & 70 & 5.7 & $<50$ & 2.42 & 2.46 & -0.14 & 7.7 \\
\hline $78-10-0$ & 82 & Lower Miocene & Pale orange $\mathrm{CaCO}_{3}$ ooze, $10 \%$ radiolarians & 19.3 & 69 & 5.7 & 240 & 2.47 & 2.78 & - & 7.9 \\
\hline $78-17-4$ & 151 & Upper Oligocene & Pale green-blue $\mathrm{SiO}_{2}-\mathrm{CaCO}_{3}$ ooze & 19.9 & 71 & - & $<50$ & 3.10 & 2.92 & -0.09 & 7.7 \\
\hline $78-25-5$ & 227 & Upper Oligocene & Light green chalk, $5-10 \%$ radiolarians & 19.9 & - & - & 200 & 2.84 & 3.06 & -0.05 & 7.7 \\
\hline $78-31-2$ & 276 & Upper Oligocene & Pale yellow-orange chalk, $5-10 \%$ radiolarians & 19.8 & 64 & 5.7 & $<50$ & 3.08 & 2.81 & -0.05 & 7.8 \\
\hline $79-2-4$ & 65 & Upper Miocene & Pale yellow-green-purple $\mathrm{CaCO}_{3}-\mathrm{SiO}_{2}$ ooze & 19.6 & 66 & 5.7 & 2700 & 2.86 & 2.70 & -1.65 & 7.6 \\
\hline $79-6-5$ & 331 & Lower Miocene & Light grey-green chalk, $\mathrm{SiO}_{2}$ ooze & 20.0 & - & - & 450 & 3.30 & 3.68 & +0.70 & 7.7 \\
\hline 79-11-CC & 373 & Lower Miocene & Light grey-green banded chalk, $5 \%$ radiolarians & 19.7 & 70 & 6.4 & - & 3.54 & 3.02 & +0.39 & 7.6 \\
\hline \multirow[t]{2}{*}{$83-2-6$} & 13 & Pleistocene & Blue-grey $\mathrm{SiO}_{2}-\mathrm{CaCO}_{3}$ ooze; glauconite, plagonite & 19.6 & 71 & 5.8 & 7800 & 2.52 & 2.40 & -3.31 & 7.7 \\
\hline & 8 & Upper Miocene & Interbedded green $\mathrm{SiO}_{2}-\mathrm{CaCO}_{3}$ ooze & 19.7 & 70 & - & 2900 & 3.02 & 2.07 & -3.68 & 7.7 \\
\hline $84-1-4$ & 5 & Pleistocene & Interbedded dark green $\mathrm{SiO}_{2}-\mathrm{CaCO}_{3}$ ooze; volcanics & 19.4 & 64 & 6.5 & 2400 & 4.98 & 4.54 & -13.76 & 7.7 \\
\hline $84-17-1$ & 145 & Pliocene & Interbedded light green $\mathrm{SiO}_{2}-\mathrm{CaCO}_{3}$ chalk & 19.8 & 69 & - & 430 & 1.87 & 1.68 & -0.94 & 7.2 \\
\hline \multicolumn{4}{|c|}{ Average Seawater } & 19.4 & 67 & 4.5 & 2 & 2.6 & 2.6 & 0 & 8.2 \\
\hline
\end{tabular}

aHole, core, section.

bDepth in sediment column.

cShipboard data. 
TABLE 2

Trace Constituents, Interstitial Water, Leg 9 (from 100-millileter samples)

\begin{tabular}{|c|c|c|c|c|c|c|c|c|}
\hline $\begin{array}{l}\text { Sample }^{a} \\
\text { Number }\end{array}$ & $\begin{array}{c}\text { Depth }^{b} \\
(\mathrm{~m})\end{array}$ & $\begin{array}{c}\mathrm{Fe} \\
(\mu \mathrm{g} / \mathrm{kg})\end{array}$ & $\begin{array}{c}\text { Co } \\
(\mu \mathrm{g} / \mathrm{kg})\end{array}$ & $\begin{array}{c}\mathrm{Ni} \\
(\mu \mathrm{g} / \mathrm{kg})\end{array}$ & $\underset{(\mu \mathrm{g} / \mathrm{kg})}{\mathrm{Cu}}$ & $\underset{(\mu \mathrm{g} / \mathrm{kg})}{\mathrm{Mn}}$ & $\underset{(\mathrm{mg} / \mathrm{kg})}{\mathrm{Si}_{3}}$ & $\begin{array}{c}\mathrm{PO}_{4}{ }^{\mathrm{c}} \\
(\mathrm{mg} / \mathrm{kg})\end{array}$ \\
\hline 77B-19-1 & 171 & 70 & $<2.0$ & 50 & 5 & 130 & 30.0 & 2.0 \\
\hline $79-3-6$ & 135 & 105 & $<2.0$ & 18 & 9 & 1000 & 32.0 & 0.9 \\
\hline $82-3-2$ & 136 & 40 & $<2.0$ & 27 & 10 & 230 & 30.0 & 0.2 \\
\hline $83 \mathrm{~A}-13-4$ & 128 & 65 & $<2.0$ & 15 & 10 & 3600 & 29.5 & 0.2 \\
\hline Average Seawater & 0 & 10 & 0.1 & 2 & 3 & 2 & 3.0 & - \\
\hline \multicolumn{9}{|l|}{ aHole, core section. } \\
\hline
\end{tabular}

is no evidence for either contributions by emanations from depth, or uptake by clays during diagenesis.

The chloride and bromide values are in all cases close to those typical of seawater, although some samples seem to be enriched in both by a few per cent. This enrichment, and the scatter in the data is most likely the result of evaporation during storage and handling of samples, that is, both of these elements seem to be relatively inert to diagenetic changes occurring in the sediment column. Only where there is evidence of the presence of evaporites, such as in the Gulf of Mexico, have we found chloride and bromide concentrations significantly different from those of the overlying seawater.

The first column of total carbon dioxide values $\left(\Sigma \mathrm{CO}_{2}\right)$ given in Table 1 were obtained by laboratory manometric measurement of the carbon dioxide $\left(\mathrm{CO}_{2}\right)$ evolved from an acidified sample of water. The small sample size can lead to analytical problems, but we believe our present system has solved most of these. The coefficient of variation on replicate samples of typical size is about 1 per cent, and bicarbonate standards also give the expected volumes of carbon dioxide to within 1 per cent. It can be seen that our laboratory values and the values from the shipboard gas chromatograph show the same trends, but the agreement is not as good as it was for some previous legs. The shipboard determination is made using only 0.2 milliliter of water; therefore, analytical scatter is difficult to avoid. There is also a problem with calibration of the chromatograph, because the laboratory value is larger in almost every case. Hopefully this problem will be solved on subsequent legs, which should result in better agreement.
As can be seen from Table 1, most of the Leg 9 interstitial waters proved to be somewhat enriched in carbon dioxide compared to normal seawater, but the enrichments were in general slight. Samples from previous legs have often shown a depletion of carbon dioxide at depth. This tendency is quite pronounced at Site 84 , and is obvious at Site 77. The concentration at other Leg 9 sites is relatively constant with depth, however, and the factors necessary to cause a carbon dioxide depletion, probably by carbonate precipitation, are unknown.

The $\mathrm{C}^{13} / \mathrm{C}^{12}$ ratios of the total dissolved carbonate from the Leg 9 samples, like those from Legs 7 and 8 generally show relatively minor variation with depth and position, compared to the large isotopic variations found in interstitial water from nearshore sediments by Presley and Kaplan (1968). These authors show how biological degradation of organic matter continues after burial, leading to an increase in total dissolved carbonate and a lowering of the $\mathrm{C}^{13} / \mathrm{C}^{12}$ ratio. A good example of this is Sample 84-14.

The $\delta \mathrm{C}^{13}$ of the Leg 9 interstitial water carbonate carbon is generally somewhat lower than the +0.5 per cent characteristic of deep ocean water (Deuser and Hunt, 1969). This seems to indicate a small but measurable contribution of carbon dioxide from oxidizing organic matter, a conclusion which is consistent with the slight enrichment in dissolved carbonate shown by most samples. It is probably unrealistic to place much significance on small changes in the isotope ratio with depth, in view of the possibilities of contamination or fractionation of the small samples during handling and processing. Nevertheless, variations 
do occur, and perhaps as more samples are analyzed, a pattern will develop.

This work was partially supported by AEC grant AT(11-1)-34, P.A. 134.

\section{REFERENCES}

Deuser, W. G. and Hunt, J. M., 1969. Stable isotope ratios of dissolved inorganic carbon in the Atlantic. Deep Sea Res. 16, 221.

Presley, B. J., 1971. Techniques for analyzing interstitial water samples. Part I: determination of selected minor and major inorganic constituents. In
E. L. Winterer et al., 1971, Initial Reports of the Deep Sea Drilling Project, Volume VII. Washington (U. S. Government Printing Office), in press.

Presley, B. J. and Claypool, G. E., 1971. Techniques for analyzing interstitial water samples. Part II: determination of total dissolved carbonate and carbon isotope ratios. In E. L. Winterer et al., 1971, Initial Reports of the Deep Sea Drilling Project, Volume VII. Washington (U. S. Government Printing Office), in press.

Presley, B. J. and Kaplan, I. R., 1968. Changes in dissolved sulfate, calcium and carbonate from interstitial water of nearshore sediments. Geochim. Cosmichim. Acta. 32, 1037. 